\title{
Expression of Bcl- $\mathrm{x}_{\mathrm{L}}$ and loss of p53 can cooperate to overcome a cell cycle checkpoint induced by mitotic spindle damage
}

\author{
Andy J. Minn, ${ }^{1,2}$ Lawrence H. Boise, ${ }^{1}$ and Craig B. Thompson ${ }^{1-4}$ \\ ${ }^{1}$ Gwen Knapp Center for Lupus and Immunology Research, ${ }^{2}$ The Committee on Immunology, ${ }^{3}$ Howard Hughes Medical \\ Institute, Department of Medicine, and Department of Molecular Genetics and Cell Biology, The University of Chicago, \\ Chicago, Illinois 60637 USA
}

\begin{abstract}
During somatic cell division, faithful chromosomal segregation must follow DNA replication to prevent aneuploidy or polyploidy. Damage to the mitotic spindle is one potential mechanism that interferes with chromosomal segregation. The accumulation of aneuploid or polyploid cells resulting from a disrupted mitotic spindle is presumably prevented by cell cycle checkpoint controls. In the course of studying cells that overexpress the apoptosis-inhibiting protein $B c l-x_{L}$, we found that these cells have an increased rate of spontaneous tetraploidization, suggesting that apoptosis may play an important role in eliminating cells that fail to complete mitosis properly. When cells expressing Bcl- $x_{L}$ are treated with mitotic spindle inhibitors, a significant percentage reinitiate DNA replication and become polyploid. Nevertheless, the majority of cells expressing Bcl- $x_{L}$ undergo a prolonged p53-dependent cell cycle arrest following mitotic spindle damage. Unexpectedly, p53 expression is not induced in mitosis, nor does it influence $M$-phase arrest. Instead, cells with mitotic spindle damage only transiently arrest in $\mathbf{M}$ phase, and despite failing to complete mitosis, appear to proceed to $G_{1}$. During this subsequent growth factor-dependent phase, p53 is induced and mediates cell cycle arrest. In cells that do not overexpress $B c l-x_{L}$, elimination of the p53-dependent growth arrest with a dominant negative mutant also results in polyploidy after mitotic spindle damage, but under these conditions most cells die by apoptosis. Expression of $B c l-x_{L}$ and abrogation of p53 cooperate to allow rapid and progressive polyploidization following mitotic spindle damage. Our results suggest that suppression of apoptosis by bcl-2-related genes and loss of p53 function can act cooperatively to contribute to genetic instability.
\end{abstract}

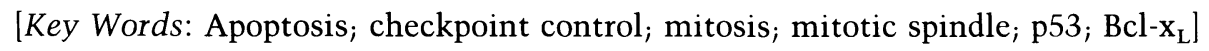

Received April 4, 1996; revised version accepted August 28, 1996.

During cell division, the orderly execution of DNA replication and chromosomal segregation, which define the $\mathrm{S}$ and $\mathrm{M}$ phases of the cell cycle, respectively, must occur with great fidelity. To ensure the interdependency of $S$ phase and $M$ phase, cells have developed mechanisms to monitor the completion of each process and halt cell cycle progression if either process is interrupted by cellular damage. Presumably, arresting damaged cells gives them a chance to repair and/or prevents their further expansion. Cell cycle checkpoint controls are genetic pathways that include proteins that sense damage, arrest the cell cycle, initiate repair, and cause apoptosis (Murray 1994, 1995). The importance of genes involved in

${ }^{4}$ Corresponding author. these pathways is emphasized by the increasing evidence that mutations in checkpoint control genes contribute to tumorigenesis and by the fact that cancer cells often have karyotypic abnormalities (Hartwell and Kastan 1994).

p53 is one of the best-studied proteins involved in cell cycle checkpoint controls and is found to be mutated in over half of all human cancers (Hollstein et al. 1991). After DNA damage, p53 is induced and acts as a sequence-specific transcription factor (Cox and Lane 1995; Haffner and Oren 1995). The cyclin dependent kinase inhibitor $\mathrm{p} 21^{\text {Waf1/Cipl }}$ is a direct transcriptional target of p53 transactivation and is partly responsible for arresting cells in $\mathrm{G}_{1}$ (El-Deiry et al. 1993; Harper et al. 1993; Deng et al. 1995). Gadd45 is another transcriptional target and is involved in stimulating DNA repair (Smith et al. 1994). Besides its role in a $G_{1}$ checkpoint, p53 also has 
been implicated in having a role in $\mathrm{G}_{2} / \mathrm{M}$. Fibroblasts null for p53 rapidly become aneuploid and polyploid in culture (Harvey et al. 1993), and after mitotic spindle damage these cells continue DNA replication in the absence of cell division and become polyploid (Cross et al. 1995). Interestingly, arrest after mitotic spindle damage is not dependent on $\mathrm{p}^{2} 1^{\text {Waf1/Cip1 }}$ (Deng et al. 1995).

Apoptosis is also being recognized as an important genetic mechanism in controlling cancer. Increasing the apoptotic threshold may be important for tumor growth because, in addition to causing proliferation, oncogene expression is often associated with increased programmed cell death (Evan et al. 1995). Additionally, an elevated apoptotic threshold contributes to radiation and chemotherapy resistance (Fisher 1994). p53 is also able to mediate apoptosis. Loss of p53 prevents thymocytes from undergoing apoptosis after gamma irradiation (Clarke et al. 1993; Lowe et al. 1993b) and decreases the efficacy of chemotherapy in vitro (Lowe et al. 1993a) and in vivo (Lowe et al. 1994). Loss of p53-mediated apoptosis also potentially contributes to tumorigenesis in conjunction with the loss of tumor suppressor genes such as $r b$ (Haffner and Oren 1995) or the gain of oncogenes such as c-myc (Evan et al. 1995).

The inappropriate expression of antiapoptosis genes including members of the $b c l-2$ family is another way to raise the apoptotic threshold of cancer cells (Hockenbery 1995). Overexpression of either Bcl-2 or the related protein $\mathrm{Bcl}-\mathrm{x}_{\mathrm{L}}$ can protect tumor cells from a wide variety of apoptotic stimuli and confers a multidrug resistance phenotype (Miyashita and Reed 1993; Dole et al. 1994; Minn et al. 1995). Recent evidence shows that Bcl- $\mathrm{x}_{\mathrm{L}}$ can be highly expressed in both primary tumors and tumor cell lines (Dole et al. 1995; Schlaifer et al. 1995).

One function of cell cycle checkpoints is to prevent the expansion of cells with unrepaired genetic damage. In theory, mutations in any of numerous genes involved in a checkpoint pathway could result in accumulation of damaged cells. These include genes involved in sensing the damage, causing cell cycle arrest, initiating repair, or inducing apoptosis. Whether most cell cycle checkpoint controls are simple linear pathways or involve several independent pathways remains unclear. In a linear pathway, apoptosis may require cell cycle arrest, and simply disrupting the arrest mechanism may prevent death and allow expansion of damaged cells. Alternatively, if arrest and apoptosis are controlled independently, disrupting cell cycle arrest would still allow damaged cells to undergo apoptosis. Independent control of cell cycle arrest and apoptosis predicts that the expansion of cells with abnormalities would occur only if both pathways are perturbed, a prediction that is in accord with a multihit model of carcinogenesis. In the work presented here, we address these issues in the context of a cell cycle checkpoint that is responsive to mitotic spindle damage. Damage induced by agents that disrupt the mitotic spindle initiates a p53-dependent cell cycle arrest and causes apoptosis in a manner that is p53-independent and inhibitable by Bcl- $\mathrm{x}_{\mathrm{L}}$.

\section{Results}

Cells expressing Bcl- $x_{L}$ have an increased propensity to become polyploid

Cells transfected with $b c l-x_{L}$, an antiapoptosis gene, have an increased propensity to become tetraploid after passage in cell culture when compared with cells transfected with a control vector. This was first noticed when the DNA content of murine FL5.12 cells transfected with $b c l-x_{L}$ was measured during continuous passage in vitro. Using starting diploid clones, these cells often became tetraploid after only 2-3 weeks of culture.

These initial observations prompted us to further explore the relationship between $\mathrm{Bcl}-\mathrm{x}_{\mathrm{L}}$ expression and mechanisms involved in the control of ploidy. To assess whether Bcl- $\mathrm{x}_{\mathrm{L}}$ enhanced the rate of spontaneous tetraploidization, FL5.12 cells were transfected with either a Bcl- $\mathrm{x}_{\mathrm{L}}$ expression vector (FL5-Bcl- $\mathrm{x}_{\mathrm{L}}$ ) or a Neo control vector (FL5-Neo). These bulk transfected populations were then cloned by limiting dilution, and after expansion, the percentage of tetraploid clones was examined. After limiting dilution cloning, $30.2 \%$ of the expanded FL5-Bcl- $\mathrm{x}_{\mathrm{L}}$ clones were tetraploid, compared with $4.2 \%$ of the expanded FL5-Neo clones (Table 1). This result suggests that $\mathrm{Bcl}-\mathrm{x}_{\mathrm{L}}$ expression is able to enhance the rate of spontaneous tetraploidization.

One way cells can become tetraploid is through disruption of the mitotic spindle and the failure of checkpoint controls to either arrest or repair the cells. To determine whether Bcl- $\mathrm{x}_{\mathrm{L}}$ influenced the fidelity of a mitotic spindle checkpoint, we treated FL5-Neo and FL5$B c l-x_{L}$ cells with nocodazole, a drug which disrupts the mitotic spindle by inhibiting microtubule polymerization. As seen in Figure 1, both FL5-Neo and FL5-Bcl- $\mathrm{x}_{\mathrm{L}}$ cells arrested with a predominantly $4 \mathrm{~N}$ DNA content after $24 \mathrm{hr}$ of nocodazole exposure. This implies that Bcl- $x_{L}$ does not affect the initial ability of checkpoint controls to arrest cells in $M$ phase in response to mitotic spindle disruption. During the arrest, FL5-Neo cells rapidly lost viability in the presence of nocodazole. By $72 \mathrm{hr}$, $<10 \%$ of FL5-Neo cells were viable, and of those viable cells $15 \%$ had escaped the cell cycle arrest to give rise to cells with a greater than $4 \mathrm{~N}$ DNA content. In contrast, cells expressing Bcl- $\mathrm{x}_{\mathrm{L}}$ were $\sim 75 \%$ viable after $72 \mathrm{hr}$ of nocodazole treatment and $40 \%$ of those cells had a

Table 1. Spontaneous tetraploidization in cells expressing $B c l-x_{L}$

\begin{tabular}{lccc}
\hline Cell type & $\begin{array}{l}\text { Number of } \\
\text { clones analyzed }\end{array}$ & $\begin{array}{l}\text { Number } \\
\text { tetraploid }\end{array}$ & $\begin{array}{l}\text { Percent } \\
\text { tetraploid }\end{array}$ \\
\hline FL5-Neo & 48 & 2 & 4.2 \\
FL5-Bcl- $x_{\mathrm{L}}$ & 76 & 23 & $30.2^{\mathrm{a}}$ \\
\hline
\end{tabular}

FL5.12 cells were transfected with either a Bcl- $\mathrm{x}_{\mathrm{L}}$ expression vector (FL5 Bcl- $\mathrm{x}_{\mathrm{L}}$ ) or an empty Neo control vector (FL5-Neo). After selection, the bulk transfectants were cloned by limiting dilution. Clones were expanded and processed for DNA content analysis by flow cytometry. ${ }^{a} P<0.01$. 
A

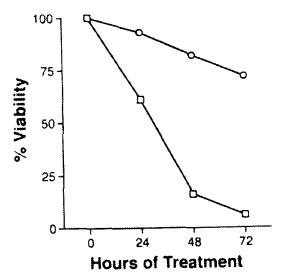

B
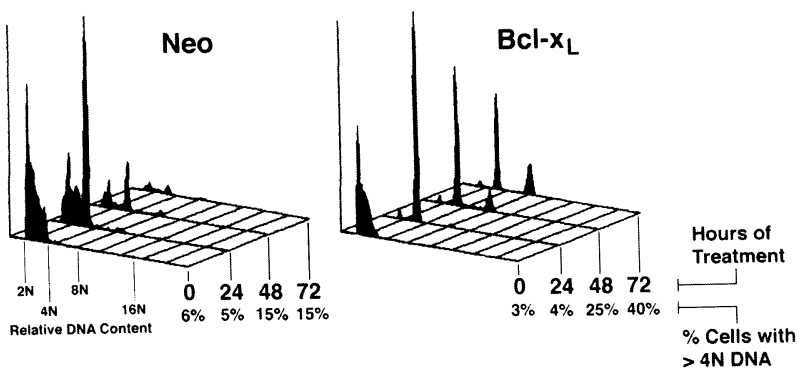

Figure 1. Bcl- $\mathrm{x}_{\mathrm{L}}$ expression promotes the accumulation of polyploid cells after mitotic spindle damage. FL5.12 cells were stably transfected with the pSFFV-Neo expression vector with a $\mathrm{Bcl}-\mathrm{x}_{\mathrm{L}} \mathrm{cDNA}$ insert $\left(\mathrm{Bcl}-\mathrm{x}_{\mathrm{L}}\right)(\mathrm{O})$ and an empty expression vector as a control $(\mathrm{Neo})(\square)$. Cells were treated with nocodazole for the indicated times. $(A)$ At each time, cells were harvested and viability was quantitated by determining the percentage of subdiploid cells. $(B)$ Cells were also processed for cell cycle analysis by flow cytometry of propidium iodide-stained cells. Shown are three-dimensional representations of overlaid DNA histograms. The $\mathrm{x}$-axis corresponds to relative DNA content, as marked on the left graph. The z-axis represents hr of nocodazole treatment, as marked, and below these markings is the percentage of cells with a $>4 N$ DNA content. These data are representative of at least three independent experiments.

greater than $4 \mathrm{~N}$ DNA content. These experiments yielded similar results when done with various doses of nocodazole or vincristine (data not shown). Additionally, when nocodazole or vincristine was removed from FL5Bcl- $\mathrm{x}_{\mathrm{L}}$ cells at 48 and $72 \mathrm{hr}$ of treatment, cells reinitiated exponential growth and the majority of the recovered cells were tetraploid. In contrast, the recovered FL5-Neo cells remained mainly diploid (data not shown).

\section{FL5.12 Cells have functional p53}

Because it has been reported previously that cells mutated or null for p53 have elevated rates of polyploidy and aneuploidy, the p53 status of FL5.12 cells was investigated. The best characterized role for p53 is in the $G_{1}$ arrest following DNA damage (Kastan et al. 1992; Kuerbitz et al. 1992). Thus, FL5-Neo and FL5-Bcl- $x_{L}$ cells were irradiated with 5 Gy gamma radiation and analyzed for p53 induction and p53-dependent $G_{1}$ arrest. FL5.12 cells rapidly and transiently induced p 53 protein after irradiation (Figure 2A). p53 protein levels peaked between $30 \mathrm{~min}$ and $2 \mathrm{hr}$ and returned to basal levels shortly thereafter. When an asynchronous population of either FL5-Neo or FL5-Bcl- $\mathrm{x}_{\mathrm{L}}$ cells was irradiated, cell cycle analysis by bromodeoxyuridine (BrdU) incorporation and DNA staining demonstrated that at $9 \mathrm{hr}$ postir-
A

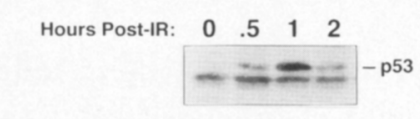

B

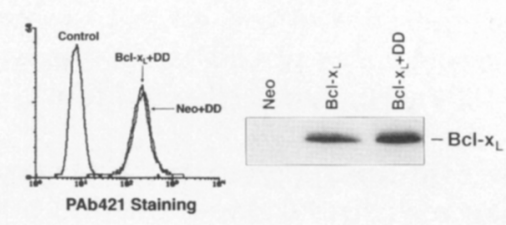

C

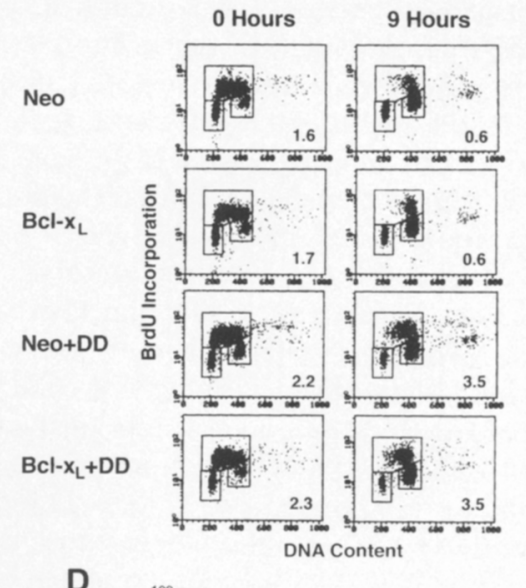

D

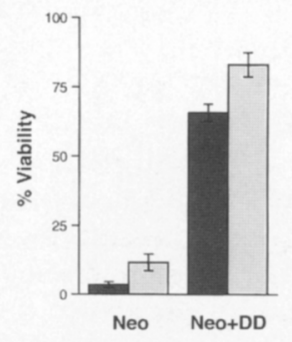

Figure 2. FL5.12 cells have functional p 53 and a dominant negative p53 protein is able to abrogate both p53-dependent cell cycle arrest and p53-dependent apoptosis. (A) FL5-Neo cells were gamma irradiated at $5 \mathrm{~Gy}$. At the indicated times postirradiation, cell lysates were made and analyzed by immunoblotting for p53. The position of $\mathrm{p} 53$ is indicated. The lower band seen on the blot is the result of nonspecific hybridization of the antibody. (B) FL5.12 cells were stably cotransfected with a Bcl$\mathrm{x}_{\mathrm{L}}$ expression vector and a DD expression vector $\left(\mathrm{Bcl}-\mathrm{x}_{\mathrm{L}}+\mathrm{DD}\right)$ or an empty expression vector and a DD expression vector (Neo $+\mathrm{DD}$ ). Clones were derived by limiting dilution. (Left) Expression levels of DD for two representative clones determined by flow cytometry of cells intracellularly stained using PAb421, an anti-p53 antibody that recognizes DD and endogenous p53. (Right) Immunoblot demonstrating expression levels for $\mathbf{B c l}-\mathbf{x}_{\mathbf{L}}$. $(C)$ The indicated cells were gamma irradiated at $5 \mathrm{~Gy}$ and pulsed with BrdU at 0 and $9 \mathrm{hr}$ postirradiation. Two-color cell cycle analysis using flow cytometry is presented with BrdU incorporation on the $y$-axis and propidium iodide DNA staining on the $x$-axis. Gates are drawn around the $G_{1}, S$, and $G_{2} / M$ cell cycle populations. The bottom left gate is $\mathrm{G}_{1}$; the top gate is $\mathrm{S}_{\text {; }}$ and the bottom right gate is $G_{2} / M$. The number in the lower right-hand corner of each graph is the ratio of the percentage of cells in $\mathrm{S}$ to the percentage of cells in $\mathrm{G}_{1}$. $(D)$ The survival of FL5-Neo (Neo) and FL5-Neo + DD (Neo + DD) cells following treatment with either $1 \mu \mathrm{g} / \mathrm{ml}$ of etoposide (dark gray bars) or by irradiating with 5 Gy gamma radiation (light gray bars) was assayed as described in Materials and Methods. Shown is cell viability at $18 \mathrm{hr}$ calculated as a percentage of an untreated control (means \pm standard deviations, $n=4$ ). 
radiation both FL5-Neo and FL5-Bcl- $\mathrm{x}_{\mathrm{L}}$ cells showed a distinct population of cells arrested in $G_{1}$ (Figure 2C). Furthermore, the ratio of the percentage of cells in $S$ phase to the percentage of cells in $G_{1}$ phase decreased from 1.6 to 0.6 in FL5-Neo cells and from 1.7 to 0.6 in FL5-Bcl- $\mathrm{x}_{\mathrm{L}}$ cells.

To further confirm the presence of functional p53 in FL5.12 cells, we wished to show that the $G_{1}$ arrest phenotype was p53-dependent. For this purpose, a dominant negative p53 miniprotein (DD) that comprises the last 89 amino acids of wild-type murine p53 was used (Shaulian et al. 1992). DD oligomerizes with endogenous p53 and inhibits p53 from binding to its DNA consensus site. FL5.12 cells were cotransfected with either a DD expression vector and a Bcl- $\mathrm{x}_{\mathrm{L}}$ expression vector or a DD expression vector and a Neo control vector to create the stable cell lines FL5-Bcl- $\mathrm{x}_{\mathrm{L}}+$ DD and FL5-Neo + DD, respectively. Clones of each cell line were screened for expression of DD by flow cytometry of cells intracellularly stained with PAb421, an anti-p53 antibody that recognizes both DD and the endogenous p53 stabilized by DD. FL5-Bcl- $\mathrm{x}_{\mathrm{L}}+$ DD and FL5-Neo + DD clones that stained similarly with PAb421 were chosen. Additionally, the FL5-Bcl- $x_{L}+$ DD clones expressed similar levels of Bcl- $x_{L}$ compared with the FL5-Bcl- $x_{L}$ cells. Several clones were characterized, but shown here are representative clones of FL5-Neo + DD and FL5-Bcl- $\mathrm{x}_{\mathrm{L}}+\mathrm{DD}$ (Figure 2B). As seen in Figure 2C, DD effectively abrogated the DNA damage-induced $G_{1}$ arrest in both Neo and $B c l-x_{L}$ backgrounds, as indicated by the increase in the $S$ to $G_{1}$ ratio $9 \mathrm{hr}$ postirradiation.

Because $\mathrm{p} 53$ has also been shown to mediate apoptosis in response to DNA damage, the ability of FL5.12 cells to undergo p53-dependent apoptosis after either irradiation or treatment with etoposide was examined. As seen in Figure 2D, FL5-Neo cells rapidly died after either etoposide treatment or irradiation. Stable transfection of the DD minigene was able to inhibit cell death under these conditions. Thus, the p53 expressed by FL5.12 cells is capable of inducing $G_{1}$ cell cycle arrest and promoting apoptosis in response to DNA damage.

\section{p53 is induced in cells after mitotic spindle damage}

Knowing that FL5.12 cells express functional p53 and that p53 has been implicated in $G_{2} / M$ checkpoint controls, we determined whether p53 was induced after treatment with nocodazole. FL5-Bcl- $\mathrm{x}_{\mathrm{L}}$ cells were treated with nocodazole for $72 \mathrm{hr}$, and p53 expression was analyzed by immunoblotting (Figure 3A). p53 was induced and peaked between 8 and $48 \mathrm{hr}$ of treatment. By $72 \mathrm{hr}$, p53 levels declined despite the continuous presence of nocodazole. p53 induction was similar in FL5-Neo cells (data not shown).

As a test for p53 function after nocodazole treatment, FL5-Bcl- $\mathrm{x}_{\mathrm{L}}$ cells were transfected with a CAT reporter construct that contained p53-specific DNA binding sites upstream of the promoter. Figure $3 \mathrm{~B}$ demonstrates that p53 transactivated the reporter, and that this transactivation was induced more than threefold by nocodazole
A

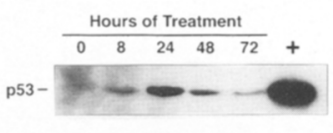

B

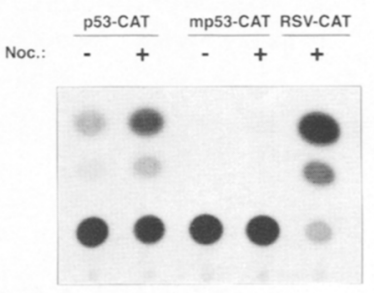

C

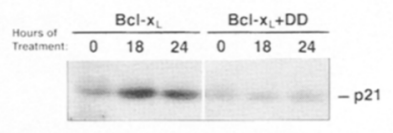

Figure 3. p53 is induced and able to transactivate gene expression after mitotic spindle damage. $(A)$ FL5-Bcl- $\mathrm{x}_{\mathrm{L}}$ cells were cultured with nocodazole for the indicated times. At each time, cell lysates were made and analyzed by immunoblotting for $\mathrm{p} 53$. $1+\mid$ Positive control lane for p53. (B) FL5-Bcl- $\mathrm{x}_{\mathrm{L}}$ cells were transfected with CAT reporter constructs and either left in media alone $(-)$ or treated with nocodazole (Noc.) $6 \mathrm{hr}$ after transfection $(+1$. Cells were harvested for CAT assay at $48 \mathrm{hr}$ posttransfection. Reporter constructs consisted of a basal promoter and the CAT gene either downstream of $\mathrm{p} 53$-specific DNA binding sites (p53-CAT), mutant p53 DNA binding sites (mp53CAT), or the RSV LTR (RSV-CAT). Equal transfection efficiencies of p53-CAT and mp53-CAT transfected cells were determined by CD20 surface staining after cotransfection with a CD20 reporter construct. These data are representative of two independent experiments. (C) FL5-Bcl- $\mathrm{x}_{\mathrm{L}}$ cells and FL5-Bcl- $\mathrm{x}_{\mathrm{L}}+$ DD cells were treated with nocodazole for the indicated times. At each time, cell lysates were made and analyzed by immunoblotting for $\mathrm{p} 21^{\text {Waf1/Cipl. }}$

treatment. Little to no reporter activity was detected in cells transfected with a CAT reporter construct containing mutated p53 DNA binding sites. In addition, p21 Waf1/Cip1, a direct transcriptional target for p53, was also induced at the protein level by nocodazole treatment (Fig. 3C). Induction of $\mathrm{p} 21^{\text {Waf1/Cipl }}$ after nocodazole treatment is dependent on $\mathrm{p} 53$, as no induction was seen in cells transfected with DD.

Abrogation of p53 function and expression of Bcl- $x_{L}$ cooperatively allow cells with mitotic spindle damage to continue cell cycle progression

The induction of p53 expression after nocodazole treatment suggests that p53 may function in a checkpoint control that prevents cell cycle progression and/or causes apoptosis in cells with a disrupted mitotic spindle. To test this, FL5-Neo + DD and FL5-Neo cells were treated with nocodazole, and cell viabilities and DNA histograms were determined over the course of $72 \mathrm{hr}$. Expression of DD had only a marginal effect on nocodazole-induced cell death because both FL5-Neo and FL5- 
$\mathrm{Neo}+\mathrm{DD}$ cells died at similar rates over a treatment course of 3 days (Figure 4A).

Despite marginal differences in viability, DD-expressing cells displayed a dramatically different cell cycle profile compared with FL5-Neo cells. In contrast to FL5-Neo cells, which predominantly remained arrested with a $4 \mathrm{~N}$ DNA content after $72 \mathrm{hr}$ of nocodazole exposure, FL5$\mathrm{Neo}+\mathrm{DD}$ cells continued progressing through the cell cycle despite the presence of mitotic spindle damage (Figure 4B). Between 24 and $48 \mathrm{hr}$, the majority of surviving FL5-Neo + DD cells had a DNA content between $4 \mathrm{~N}$ and $8 \mathrm{~N}$, and at $72 \mathrm{hr}$, a significant fraction had a $>8 \mathrm{~N}$ DNA content. At the end of $72 \mathrm{hr}, 68 \%$ of the surviving FL5-Neo + DD cells had a $>4$ N DNA content compared with only $19 \%$ of the FL5-Neo cells. These data demonstrate that p53 is a necessary component of a checkpoint control that keeps cells with mitotic spindle damage from reinitiating DNA synthesis.

Because Bcl- $\mathrm{x}_{\mathrm{L}}$ expression is able to enhance the accumulation of polyploid cells after mitotic spindle damage despite the induction of functional p53, and because introduction of DD only slightly influences viability after

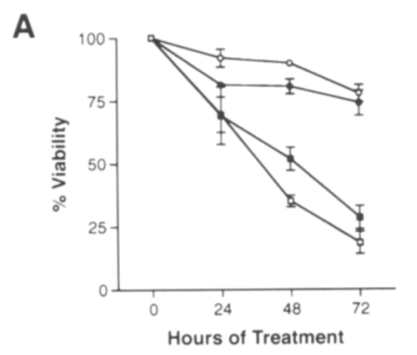

B

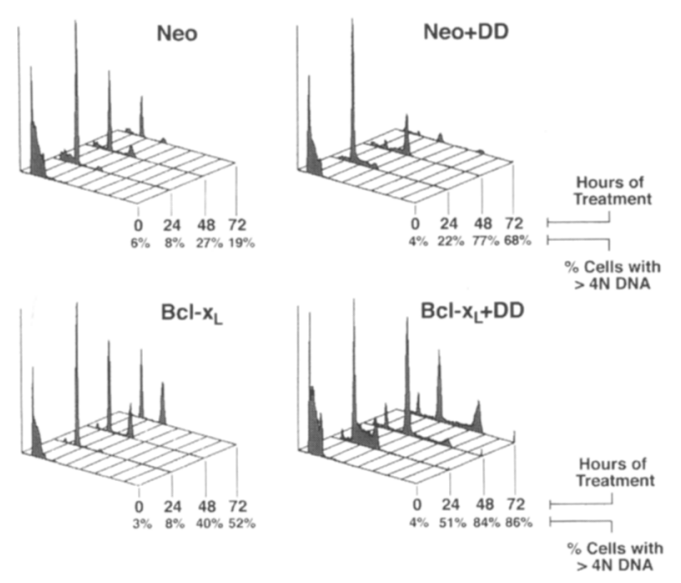

Figure 4. Expression of $\mathrm{Bcl}-\mathrm{x}_{\mathrm{L}}$ and abrogation of $\mathrm{p} 53$ function cooperatively allow accumulation and cell cycle progression of polyploid cells after mitotic spindle damage. $(A)$ The indicated cells were treated with nocodazole for $72 \mathrm{hr}$. Every $24 \mathrm{hr}$, cell viability was determined by propidium iodide exclusion (means \pm S.D., $n=6)$. (O) Bcl-x $\mathrm{L}_{\mathrm{L}}(\mathbf{O}) \mathrm{Bcl}-\mathrm{x}_{\mathrm{L}}+\mathrm{DD} ;(\square) \mathrm{Neo}_{;}(\mathbf{\square}) \mathrm{Neo}+$ DD. $(B)$ The indicated cells were treated with nocodazole for 72 hr. Every $24 \mathrm{hr}$, cells were harvested and processed for cell cycle analysis by flow cytometry of propidium iodide-stained cells as described in the legend for Fig. 1. These data are representative of at least three independent experiments. mitotic spindle damage, these results predict that after mitotic spindle damage the loss of $\mathrm{p} 53$ and the expression of $\mathrm{Bcl}-\mathrm{x}_{\mathrm{L}}$ might work in at least an additive fashion to further increase the percentage of cells with a $>4 \mathrm{~N}$ DNA content. To test this, FL5-Bcl- $\mathrm{x}_{\mathrm{L}}+$ DD cells were also treated with nocodazole. Figure $4 \mathrm{~A}$ shows that the viabilities of FL5-Bcl- $\mathrm{x}_{\mathrm{L}}$ and FL5-Bcl- $\mathrm{x}_{\mathrm{L}}+$ DD cells were similar. Both cell types were $>75 \%$ viable after $72 \mathrm{hr}$ of nocodazole exposure. However, whereas Bcl- $\mathrm{x}_{\mathrm{L}}$ expression alone permitted a gradual increase in $8 \mathrm{~N}$ cells during the 72 -hr time course, $\mathrm{Bcl}-\mathrm{x}_{\mathrm{L}}$ expression combined with DD allowed rapid accumulation of $8 \mathrm{~N}$ and then $16 \mathrm{~N}$ cells. By $72 \mathrm{hr}, 86 \%$ of FL $5-\mathrm{Bcl}-\mathrm{x}_{\mathrm{L}}+$ DD cells had a $>4 \mathrm{~N}$ DNA content, and of these cells, most had a $>8 \mathrm{~N}$ DNA content. In contrast, only $52 \%$ of FL $5-B c l-x_{L}$ cells had a $>4 \mathrm{~N}$ DNA content and few cells had a $>8 \mathrm{~N}$ DNA content. When compared with cells that express DD alone, the introduction of $\mathrm{Bcl}-\mathrm{x}_{\mathrm{L}}$ into DD-expressing cells enhanced cell viability and the percentage of cells that continued cell cycle progression after mitotic spindle damage (Figures 4A and 4B). The increase in the percentage of cells with a $>4 \mathrm{~N}$ DNA content was not a result of a higher level of DD in FL5-Bcl- $x_{L}+$ DD cells compared with FL5-Neo + DD cells (Figure 2B). Thus, these data demonstrate that in cells with mitotic spindle damage, the inhibition of $\mathrm{p} 53$ function and the prevention of apoptosis through $\mathrm{Bcl}-\mathrm{x}_{\mathrm{L}}$ expression cooperate to overcome a checkpoint induced by mitotic spindle damage.

Enforcing p53 levels in Bcl- $x_{L}$-expressing cells inhibits cell cycle progression after mitotic spindle damage

It has been demonstrated in many systems that blocking cell death with antiapoptosis genes does not prevent growth arrest (Hockenbery 1995). Therefore, we were interested in understanding why expression of an antiapoptosis gene like $b c l-x_{L}$ resulted in the accumulation of polyploid cells in response to mitotic spindle damage.

The kinetics of p53 expression after nocodazole treatment indicated that $\mathrm{p} 53$ levels did not remain elevated during the entire $72 \mathrm{hr}$ of treatment (Figure 3A). The 48 hr time point at which p53 levels began declining coincided with the time at which $4 \mathrm{~N}$ cells began to accumulate in FL5-Bcl- $x_{L}$ cultures (Figs. 1 and $4 B$ ). This suggests that a potential mechanism by which $\mathrm{Bcl}-\mathrm{x}_{\mathrm{L}}$ influences the ability of cells to remain arrested is by allowing cells to survive to a point after which p53 is downregulated, perhaps because of adaptation of the checkpoint pathway. Cells that are no longer able to maintain p53 normally would die, but when apoptosis is prevented by Bcl- $x_{L}$, these cells proceed to replicate their DNA. As a test of this model, we cotransfected FL5.12 cells with $b c l-x_{L}$ and a temperature-sensitive $p 53$ (tsp53). For this mutant, incubation at the permissive temperature of $32^{\circ} \mathrm{C}$ leads to high-level expression of p53 in a wild-type conformation, resulting in $\mathrm{G}_{1}$ arrest (Figure 5, cf. FL5Bcl- $x_{L}$ and FL5-Bcl- $x_{L}+$ tsp53). To determine if maintaining high levels of wild-type p53 in cells expressing $\mathrm{Bcl}-\mathrm{x}_{\mathrm{L}}$ could inhibit cell cycle progression after mitotic 


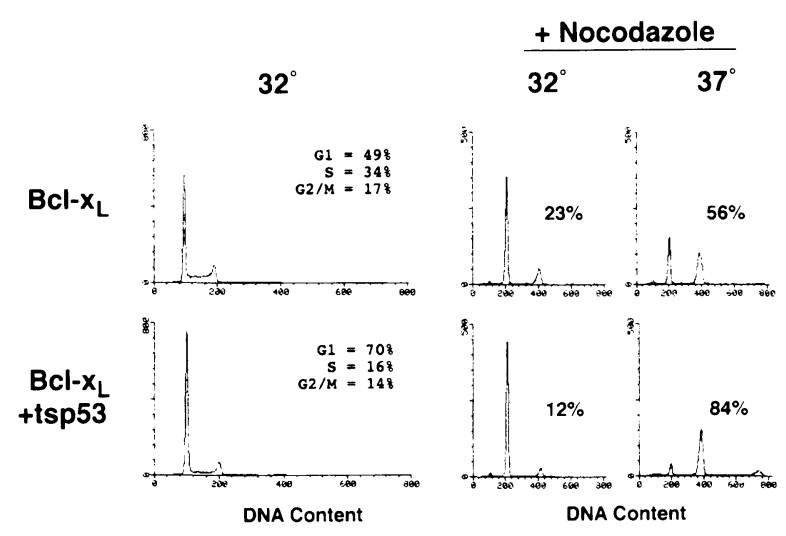

Figure 5. Enforced $\mathrm{p} 53$ expression inhibits the ability of Bcl- $\mathrm{x}_{\mathrm{L}}$ to promote polyploidy after mitotic spindle damage. FL5.12 cells, stably cotransfected with $b c l-x_{L}$ and a temperature-sensitive $p 53\left(b c l-x_{L}+t s p 53\right)$ or transfected with $b c l-x_{L}$ alone $(b c l$ $x_{L}$ l, were either treated with nocodazole for $72 \mathrm{hr}$ or left untreated for $48 \mathrm{hr}$. One set of duplicate samples were maintained at $37^{\circ} \mathrm{C}$ and the other set was maintained at $32^{\circ} \mathrm{C}$. Cells were then harvested for propidium iodide staining, followed by flow cytometry. The percentage of cells in $G_{1}, S$, and $G_{2} / M$ is indicated in the upper right of the DNA histograms from the untreated samples. The percentage of cells with a $>4 \mathrm{~N}$ DNA content are shown for each histogram of the treated samples. These data are representative of three independent experiments performed with two different clones.

spindle damage, FL5-Bcl- $x_{\mathrm{L}}+$ tsp53 cells were treated with nocodazole and shifted to $32^{\circ} \mathrm{C}$. As seen in Figure 5, enforced expression of a wild-type form of p53 in FL5Bcl- $\mathrm{x}_{\mathrm{L}}+$ tsp53 cells inhibited cell cycle progression after $72 \mathrm{hr}$ of nocodazole treatment compared with FL5-Bcl- $\mathrm{x}_{\mathrm{L}}$ cells. At the restrictive temperature of $37^{\circ} \mathrm{C}$, the tsp53 is in a mutant conformation and acts as a dominant negative. Therefore, when compared with cells expressing Bcl- $\mathrm{x}_{\mathrm{L}}$ alone, FL5-Bcl- $\mathrm{x}_{\mathrm{L}}+\mathrm{tsp} 53$ cells at $37^{\circ} \mathrm{C}$ had an increased percentage of cells with a $>4 \mathrm{~N}$ DNA content after nocodazole treatment, consistent with the data obtained from the DD transfectants. Thus, maintaining high p53 levels at later time points of nocodazole treatment is sufficient to antagonize the ability of Bcl- $\mathrm{x}_{\mathrm{L}}$ to promote the accumulation of polyploid cells.

Mitotic spindle damage induces a transient $M$ phase arrest that is not affected by either $p 53$ or Bcl- $X_{L}$

The fact that the checkpoint control that is active after mitotic spindle damage is p53 dependent and arrests cells with a $4 \mathrm{~N}$ DNA content suggests that p53 may be working to arrest cells in mitosis. To determine whether nocodazole-treated cells display a prolonged $M$-phase arrest, we analyzed three well-characterized M-phase markers: Cyclin B1 expression, MPM-2 expression, and the presence of condensed mitotic chromosomes. FL5Neo and FL5-Bcl- $x_{L}$ cells treated with nocodazole demonstrated high levels of Cyclin Bl expression at $8 \mathrm{hr}$, consistent with an accumulation of cells in $M$ phase (Figure 6A). However, Cyclin B1 levels declined to near interphase levels by $24 \mathrm{hr}$, demonstrating that the majority of the cells did not remain arrested in mitosis. A Cdc2 immunoblot showed that Cdc2 did not undergo a similar decline in expression, arguing against a general decrease in protein synthesis.

MPM-2 is an epitope whose expression is restricted to $M$ phase (Davis et al. 1983). Flow cytometry on nocodazole-treated cells intracellularly stained for MPM-2 was used to follow the percentage of cells that were in $M$ phase at various times during nocodazole treatment. The left panels of Figure 6B show that at $12 \mathrm{hr}$, nearly $50 \%$ of the FL5-Neo cells were positive for MPM-2, demonstrating that an M-phase arrest did occur; however, the percentage of MPM-2 positive cells began to decline thereafter. By $24 \mathrm{hr}$ of nocodazole treatment, the percentage of cells that were MPM-2 positive was only threefold higher than interphase levels. Thus, the decrease in MPM-2 reactive cells at $24 \mathrm{hr}$ (and at later time points; data not shown), despite evidence of a prolonged p53dependent cell cycle arrest by DNA staining, suggests

A

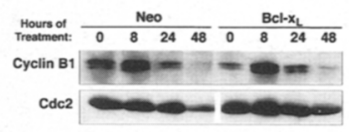

B

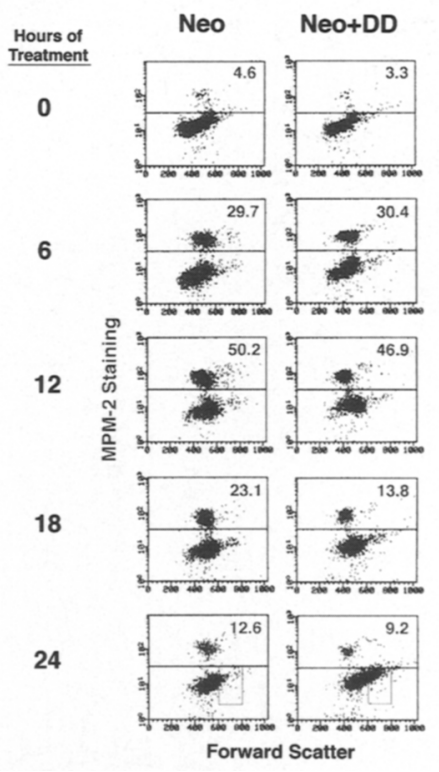

Figure 6. Mitotic spindle damage causes a transient arrest in mitosis as determined by the expression of mitotic proteins. FL5-Neo and FL5-Bcl- $\mathrm{x}_{\mathrm{L}}$ cells were treated with nocodazole for the indicated times. $(A)$ Cell lysates were made and analyzed by immunoblotting for Cyclin B1 and Cdc2. $(B)$ FL5-Neo cells and FL5-Neo + DD cells were analyzed for the percentage of cells in mitosis by flow cytometry of MPM-2 stained cells. Results are plotted with MPM-2 fluorescence on the y-axis and forward scatter on the $\mathrm{x}$-axis. The percentage of cells that are MPM-2 positive is indicated in the upper right-hand corner. For the 24 hr time point, a box is drawn that indicates the population of cells that demonstrate an increase in forward scatter. This population comprises $6.4 \%$ of the total FL5-Neo population and $22.7 \%$ of the total FL5-Neo + DD population. These data are representative of three independent experiments. 
that p53 does not cause an extended arrest in mitosis. Consistent with this interpretation, a similar analysis on FL5-Neo + DD cells showed that the kinetics of MPM-2 reactivity was nearly identical to FL5-Neo cells /right panels of Fig. 6B). However, one notable difference is that at $24 \mathrm{hr}$ the FL5-Neo + DD cells contained a large population that was MPM-2 negative and had an increase in cell size as indicated by an increase in forward light scatter (this population is boxed in Fig. 6B). This population likely reflects the failure of FL5-Neo + DD cells to undergo a p53-dependent cell cycle arrest that occurs after a transient $M$-phase arrest.

To confirm that MPM-2 staining accurately represents mitotic cells, nocodazole-treated cells were stained with both an anti-MPM-2 antibody and DAPI. Confocal microscopy demonstrated that in both FL5-Neo and FL5Bcl- $\mathrm{x}_{\mathrm{L}}$ cells, approximately half of the cells accumulated MPM-2 fluorescence at $16 \mathrm{hr}$ of nocodazole treatment, which is consistent with the flow cytometry analysis (data not shown). These cells all exhibited condensed mitotic chromosomes, and almost all cells that were MPM-2 negative exhibited decondensed chromatin, demonstrating that MPM-2 reactivity and the presence of condensed mitotic chromosomes are nearly always coincidental. In FL5-Neo cells, condensed apoptotic nuclei were also seen. By $24 \mathrm{hr}$ of nocodazole treatment, FL5-Bcl- $\mathrm{x}_{\mathrm{L}}$ cells and FL5-Neo cells predominantly exhibited interphase chromatin and were negative for MPM-2.

In response to mitotic spindle damage p53 is not induced in mitosis but during a subsequent growth phase where it mediates cell cycle arrest

Thus far, we have shown that $\mathrm{p} 53$ is induced after mitotic spindle damage and its function is important in keeping the damaged cells arrested with a 4N DNA content. However, it would seem that the cells arrested with a 4N DNA content are not necessarily arrested in mitosis. Arrest in mitosis is short and uninfluenced by p53. This suggests that the induction of p53 might occur after cells are released from $M$-phase arrest. For this reason, nocodazole-treated cells were intracellularly stained with antibodies against both p53 and MPM-2 to test directly whether mitotic cells expressed the induced p53 protein. Figure 7A shows that p53 and MPM-2 staining were mutually exclusive. At $12 \mathrm{hr}, \mathrm{MPM}-2$ staining peaked at $45 \%$, just when p53 staining became detectable. Between 12 and $24 \mathrm{hr}$, there was a $\sim 37 \%$ decrease in MPM- 2 positive cells, in contrast to the $27 \%$ gain in p53 positive cells. The loss in the percentage of MPM-2 positive cells seen from 12 to $24 \mathrm{hr}$ can be approximately accounted for by the gain in the percentage of $\mathrm{p} 53$ positive cells. At no time during the analysis was there a significant percentage of cells expressing both proteins. These data suggest that in response to mitotic spindle damage, p53 is induced after a transient mitotic arrest.

Because the nocodazole-induced $M$-phase arrest is transient and does not involve p53, we were interested in knowing the cell cycle phase that cells proceed to after $\mathrm{M}$-phase arrest. Based on kinetics, this cell cycle phase is
A

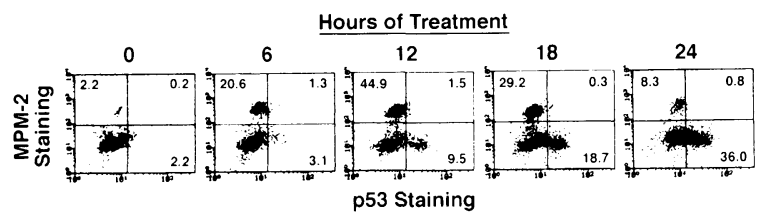

B

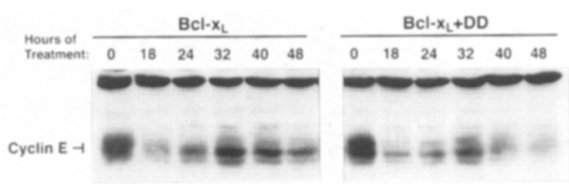

C

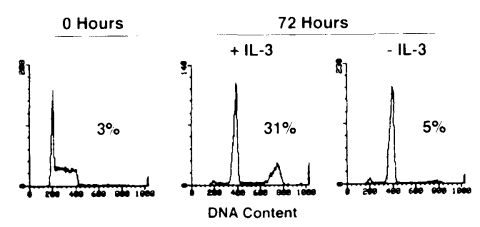

Figure 7. p53 induced after mitotic spindle damage is not expressed in cells arrested in mitosis but instead expressed in a subsequent $\mathrm{G}_{1}$-like phase. FL5-Bcl- $\mathrm{x}_{\mathrm{L}}$ cells were treated with nocodazole for the indicated times. $(A)$ These cells were intracellularly stained for both MPM-2 and p53 expression and were analyzed by flow cytometry. MPM-2 fluorescence is on the $\mathrm{y}$-axis and p53 fluorescence is on the $\mathrm{x}$-axis. Quadrants are shown and the percentage of cells in the single-positive populations and the double-positive population is given. $(B)$ FL5-Bcl$\mathrm{x}_{\mathrm{L}}$ cells and FL5-Bcl- $\mathrm{x}_{\mathrm{L}}+$ DD cells were treated with nocodazole for the indicated times. At each time point, cell lysates were made and analyzed by immunoblotting for Cyclin $\mathrm{E}$. The band at the top of the gel is nonspecific and serves as a loading control. $(C)$ At $9 \mathrm{hr}$ after addition of nocodazole, IL-3 was removed from the medium by washing and resuspending the cells in IL-3-free medium containing nocodazole. After $72 \mathrm{hr}$, cells were harvested and processed for cell cycle analysis by flow cytometry of propidium iodide-stained cells. The percentage of cells with a $>4 \mathrm{~N}$ DNA content is shown. No major differences in cell survival of FL5-Bcl- $\mathrm{x}_{\mathrm{L}}$ cells treated in the presence or absence of IL-3 were observed. These data are representative of two independent experiments.

presumably where p53 is induced and mediates cell cycle arrest. The most likely situation is that the transiently arrested cells reset to $G_{1}$. To test this, the expression pattern of Cyclin $E$, a late $G_{1}$ cyclin, during nocodazole treatment of FL5-Bcl- $x_{L}$ cells and FL5-Bcl- $x_{L}+$ DD cells was analyzed. As seen in Figure $7 \mathrm{~B}$, in both FL5-Bcl- $\mathrm{x}_{\mathrm{L}}$ cells and FL5-Bcl- $\mathrm{x}_{\mathrm{L}}+$ DD cells, nocodazole treatment caused an initial decrease in Cyclin E expression as cells transiently arrested in $M$ phase. However, in both populations of cells, Cyclin E began to reaccumulate after 24 $\mathrm{hr}$ of nocodazole treatment. In FL5-Bcl- $\mathrm{x}_{\mathrm{L}}$ cells, once $\mathrm{Cy}$ clin $\mathrm{E}$ reaccumulated its expression was maintained for the rest of the culture period. In contrast, in FL5-Bcl- $\mathrm{x}_{\mathrm{L}}$ + DD cells, once reaccumulated, Cyclin E again declined as cells began to resynthesize DNA. These data suggest that cells with mitotic spindle damage undergo a p53-dependent arrest in a state similar to late $G_{1}$.

As an independent confirmation that cells with mitotic spindle damage reset to $G_{1}$, we took advantage of 
the fact that FL5.12 cells are dependent on IL-3 for $G_{1}$ cell cycle progression. As seen in Figure $7 \mathrm{C}$, when IL-3 was removed from the media at $9 \mathrm{hr}$ of nocodazole treatment FL5-Bcl- $x_{L}$ cells did not go on to replicate their DNA. Because IL-3 is necessary for the cells to pass the $G_{1}$ restriction point, its requirement for generating cells with a $>4 \mathrm{~N}$ DNA content after mitotic spindle damage further supports that passage through a growth factordependent $G_{1}$-like phase occurs after the transient mitotic arrest.

\section{Discussion}

In this study, we show that mitotic spindle damage activates a checkpoint control that prevents DNA replication of damaged cells by causing p53-dependent cell cycle arrest and p53-independent apoptosis. If cells are prevented from undergoing apoptosis by expression of Bcl- $\mathrm{x}_{\mathrm{L}}$, we find that this promotes the accumulation of polyploid cells. Bcl- $x_{L}$ does not seem to override the checkpoint induced by mitotic spindle damage but rather allows cells to survive until the p53-dependent arrest pathway either becomes exhausted or undergoes adaptation. Once the p53-dependent checkpoint decays, Bcl- $\mathrm{x}_{\mathrm{L}}$-protected cells replicate their DNA, despite having failed to properly execute the previous $M$ phase. When p53 expression is enforced, resulting in continuously high levels of p53, DNA replication is inhibited. Further evidence that apoptosis is an important mechanism used to prevent polyploidy is the observation that cells that overexpress Bcl- $\mathrm{x}_{\mathrm{L}}$ have higher rates of spontaneous tetraploidization.

The finding that p53 is a component of a checkpoint following mitotic spindle damage is consistent with previous reports (Cross et al. 1995). We find that p53 functions to keep cells with spindle damage arrested with a $4 \mathrm{~N}$ DNA content. The introduction of DD, a dominant negative p53 miniprotein, abrogates the cell cycle arrest observed following mitotic spindle damage. These cells go on to become $8 \mathrm{~N}$ and then $16 \mathrm{~N}$ during the $72 \mathrm{hr}$ of nocodazole treatment. During the $72 \mathrm{hr}$ time course, $16 \mathrm{~N}$ cells are not seen in cells that overexpress $\mathrm{Bcl}-\mathrm{x}_{\mathrm{L}}$ alone, emphasizing the differences in the way DD and $\mathrm{Bcl}-\mathrm{x}_{\mathrm{L}}$ function. With $\mathrm{Bcl}-\mathrm{x}_{\mathrm{L}}$, cells are rescued from apoptosis and survive long enough to escape cell cycle arrest; however, these cells likely stop at the same checkpoint in the next cell cycle. In contrast, cells with DD lack the p53-mediated arrest altogether and are able to proceed through multiple rounds of DNA replication. However, these cells still lose viability at a rate comparable to wild-type cells.

The inability of DD to prevent apoptosis after mitotic spindle damage suggests that FL5.12 cells undergo cell death via p53-independent mechanisms. DD is able to inactivate p53-mediated apoptosis as demonstrated by experiments analyzing cell death after irradiation and etoposide treatment. Nevertheless, because we have used Bcl- $x_{L}$ overexpression to prevent apoptosis in our studies and Bcl- $\mathrm{x}_{\mathrm{L}}$ overexpression can inhibit both p53dependent and p53-independent apoptosis, we cannot ex- clude an additional role for p53-dependent apoptosis in preventing the development of polyploid cells following mitotic spindle damage.

Many reports have suggested that arrest and apoptosis are downstream effects dependent on p53 and important in endowing p53 with tumor-suppressing properties (Cox and Lane 1995; Haffner and Oren 1995). Under circumstances where p53 mediates cell death, cooperation between loss of p53 and overexpression of antiapoptosis genes would not be expected. However, our data suggest that under circumstances where damaged cells undergo p53-independent cell death and p53-dependent cell cycle arrest, the expression of antiapoptosis genes can cooperate with the loss of p53 to enhance the accumulation of genetically damaged cells. Following mitotic spindle damage, p53-dependent growth arrest and p53-independent apoptosis can form a partly redundant checkpoint control system to abort genetically aberrant cells. Cells suffering mitotic spindle damage that are blocked from apoptosis can still cease or dramatically slow proliferation as a result of the arrest pathway. Conversely, cells suffering mitotic spindle damage that are prevented from undergoing growth arrest can still die as a result of the cell death pathway. Elimination of both pathways can cooperatively enhance the ability of cells with mitotic spindle damage to accumulate and progress through the cell cycle.

Recent data have suggested that $\mathrm{p} 53$ has a role in $\mathrm{G}_{2}$ and/or $M$ phase of the cell cycle. p53-null fibroblasts rapidly become polyploid and aneuploid during cell passage (Harvey et al. 1993) or after treatment with a mitotic spindle poison (Cross et al. 1995). Erythroid cell lines from $\mathrm{p} 53$ knockout mice are stably diploid but are susceptible to polyploidization (Metz et al. 1995). p53 has been shown to be phosphorylated by $\mathrm{G}_{2} / \mathrm{M}$ cyclins, resulting in altered DNA binding specificity (Wang and Prives 1995). p53 expression from an inducible promoter is able to arrest cells in $\mathrm{G}_{2} / \mathrm{M}$ (Agarwal et al. 1995). However, despite these observations that seem to support a role for p53 in $G_{2} / M$, we fail to observe any evidence for such a role for p53 after mitotic spindle damage.

Our data suggest that in murine cells, $M$ phase-specific checkpoint controls that monitor mitotic spindles, as suggested by studies in yeast (Hoyt et al. 1991; Li and Murray 1991) and Xenopus (Minshull et al. 1994) and checkpoints that monitor kinetochores ( $\mathrm{Li}$ and Nicklas 1995; Rieder et al. 1995) may only lead to a transient mitotic arrest. These data are consistent with previous findings (Kung et al. 1990). However, in addition, we show that this transient $M$-phase arrest does not involve p53. Rather, after the transient M-phase arrest, cells default to what appears to be $\mathrm{G}_{1}$-like phase in which the cells are MPM-2 negative, low in Cyclin B1, high in Cyclin $\mathrm{E}$, and have interphase chromatin. It is at this point that p53 is induced and mediates growth arrest. After mitotic spindle damage, p53 may function in a pathway that senses the consequences of an abortive mitosis. An abortive mitosis may induce p53 due to DNA damage or topological structures caused by the failure to properly segregate sister chromatids. Alternatively, because p53 
has been shown to influence centrosome duplication (Fukasawa et al. 1996), the presence of more than one centrosome in a $G_{1}$ cell due to mitotic failure may also lead to p53 induction. Thus, true mitotic checkpoints can function to monitor events within $M$ phase to assure proper anaphase, whereas p53 can function subsequently to prevent cells that have failed $M$ phase from reinitiating DNA replication. Figure 8 presents a model that summarizes our findings.

The disruption of genes involved in cell cycle checkpoint controls has long been recognized as one way cells can accumulate karyotypic abnormalities. However, checkpoint controls that simply lead to growth arrest may not be enough to ensure faithful cell division. Our data demonstrate that cell death pathways can also play an important role in preventing the accumulation of genetically abnormal cells. One reason for this may be that in the presence of constant stimuli, checkpoint pathways, like other signal transduction pathways, can undergo adaptation and lose activity (Sandell and Zakian 1993). Apoptosis may provide a mechanism to abort cells before adaptation occurs.

\section{Materials and methods}

\section{Cell culture and cell transfections}

The murine prolymphocytic IL-3-dependent cell line, FL5.12 was maintained as described previously (Boise et al. 1993). To create FL5-Bcl- $\mathrm{x}_{\mathrm{L}}$ or FL5-Neo cell lines, transfection with either pSFFV-Bcl- $x_{L}$ or pSFFV-Neo (Boise et al. 1993) was performed using $10 \mu \mathrm{g}$ of plasmid, electroporated into $1 \times 10^{7}$ cells at 960 $\mu \mathrm{F}$ and $250 \mathrm{~V}$. Neomycin-resistant cells were selected with 1 $\mathrm{mg} / \mathrm{ml} \mathrm{G} 418$. Single cell clones from the bulk transfection were derived by limiting dilution cloning. Clones were screened for $\mathrm{Bcl}-\mathrm{x}_{\mathrm{L}}$ expression by immunoblotting with $2 \mathrm{Al}$, a mouse monoclonal antibody to $\mathrm{Bcl}-\mathrm{x}_{\mathrm{L}}$ (see below). To create FL5-Neo + DD, FL5-Bcl- $x_{L}+$ DD, or FL5-Bcl- $x_{L}+$ tsp53 cell lines, FL5.12 cells were cotransfected with either pCMVDD (Shaulian et al. 1992) or pLTRp53cGval135 (Yin et al. 1992) and either pSFFV-Bcl- $x_{L}$ or pSFFV-Neo. Clones containing DD were screened by flow cytometry of cells intracellularly stained with PAb421, and clones containing tsp53 were screened by immunoblotting with PAb240. Several clones from all cell lines were used in experiments and were found to give similar results.

For drug treatments, cells were resuspended in medium without G418 at a concentration of $5 \times 10^{5}$ cells $/ \mathrm{ml}$, along with

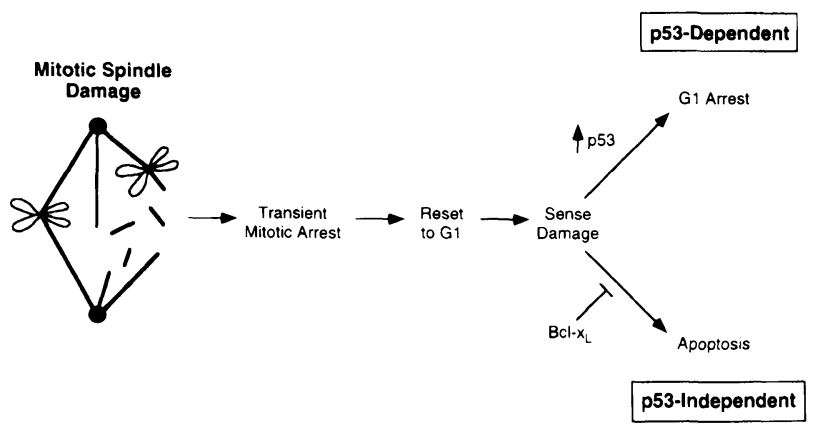

Figure 8. Proposed model for the cellular response to mitotic spindle damage. See text for details. nocodazole (Sigma). Various doses of nocodazole were tested from 0.01 to $0.6 \mu \mathrm{g} / \mathrm{ml}$; however, $0.1 \mu \mathrm{g} / \mathrm{ml}$ was generally chosen for most experiments. Cell death of FL5-Neo and FL5-Neo + DD cells in response to etoposide and irradiation was determined essentially as described previously (Canman et al. 1995). In brief, cells were washed three times and resuspended in medium without IL-3. Cells were then either irradiated with 5 Gy gamma radiation or treated with $1 \mu \mathrm{g} / \mathrm{ml}$ etoposide. Viability was determined at $18 \mathrm{hr}$ as a percentage of an untreated control.

\section{Cell viability and cell cycle analysis}

Cell viability was determined by propidium iodide exclusion, as described previously (Minn et al. 1995). The percent viability was calculated as a percentage of either the viability at $0 \mathrm{hr}$ or the viability of an untreated control. Cell cycle analysis by DNA staining alone was assayed by staining fixed cells with $0.01 \mathrm{mg} / \mathrm{ml}$ of propidium iodide. Cells were assayed by flow cytometry and the analysis was gated to exclude subdiploid cells and cell doublets. For cell cycle statistics, data was quantitated with CellFit software (Becton Dickinson) using the RFIT analysis mode. For cell cycle analysis by DNA staining and BrdU incorporation, $1 \times 10^{6}$ cells were pulsed for 30 min with $25 \mu \mathrm{M}$ of BrdU (Boehringer Mannheim), harvested, and fixed with ethanol. Fixed cells were then washed and incubated in 1 $\mathrm{ml}$ of $2.5 \mathrm{M} \mathrm{HCl}+0.1 \%$ Triton X-100 in PBS for $25 \mathrm{~min}$ at room temperature and then washed twice with $4 \mathrm{ml}$ of neutralization/wash solution $(0.5 \%$ Tween-20 in PBS). The cells were resuspended in $100 \mu \mathrm{l}$ of antibody staining solution $(50 \%$ fetal calf serum $+0.01 \%$ sodium azide in PBS) along with $4 \mu \mathrm{l}$ of FITC-conjugated anti-BrdU antibody (Boehringer Mannheim) and incubated at room temperature in the dark for $30 \mathrm{~min}$. Cells were washed twice with PBS and resuspended in $0.5 \mathrm{ml}$ of PBS. Ten micrograms of propidium iodide were added. Samples were then analyzed by flow cytometry.

\section{Immunoblotting}

Protein lysates were made by lysing cells in RIPA (150 mM $\mathrm{NaCl}, 1 \% \mathrm{NP}-40,0.5 \% \mathrm{DOC}, 0.1 \%$ SDS, and $50 \mathrm{~mm}$ Tris at $\mathrm{pH}$ $7.5)$ supplemented with $8 \mu \mathrm{g} / \mathrm{ml}$ aprotinin, $2 \mu \mathrm{g} / \mathrm{ml}$ leupeptin, and $170 \mu \mathrm{g} / \mathrm{ml}$ PMSF. Western blots were prepared as described previously (Minn et al. 1995) and blocked with blotto (5\% nonfat milk and $0.05-0.2 \%$ Tween-20) for $1 \mathrm{hr}$ at room temperature. The blot was then probed with either a 1:10000 dilution of $2 \mathrm{Al}$ (mouse monoclonal anti-Bcl- $\mathrm{x}_{\mathrm{L}}$ antibody) (Boise et al. 1995), 1 $\mu \mathrm{g} / \mathrm{ml}$ of PAb240 (mouse monoclonal anti-p53 antibody, Santa Cruzl, $1 \mu \mathrm{g} / \mathrm{ml}$ of a mouse monoclonal anti-Cyclin B1 antibody (Pharmingen), $1 \mu \mathrm{g} / \mathrm{ml}$ of a mouse monoclonal anti-Cdc2 antibody (\#sc-54, Santa Cruz), $0.5 \mu \mathrm{g} / \mathrm{ml}$ of a rabbit polyclonal antip21 antibody (\#sc-397, Santa Cruz), or $0.5 \mu \mathrm{g} / \mathrm{ml}$ of a rabbit polyclonal anti-Cyclin E antibody (\#sc-481, Santa Cruz) for $1 \mathrm{hr}$ at room temperature in blotto. The blot was washed and developed with the ECL system (Amersham).

\section{Intracellular staining for flow cytometry}

For intracellular staining, $1 \times 10^{6}$ cells were fixed with $1 \%$ paraformaldehyde in PBS for $10 \mathrm{~min}$ at room temperature. Cells were then washed in wash solution $(0.03 \%$ saponin in PBS) and resuspended in $100 \mu \mathrm{l}$ of staining solution $10.3 \%$ saponin and $20 \%$ goat serum in PBS) along with $1 \mu \mathrm{g}$ of PAb421 (Oncogene Science) and/or $0.5 \mu \mathrm{l}$ of a mouse monoclonal anti-MPM- 2 antibody (Upstate Biotechnology) for $30 \mathrm{~min}$ at $4^{\circ} \mathrm{C}$. Cells were then washed twice with wash solution and resuspended in 100 $\mu \mathrm{l}$ of staining solution without goat serum. For p53 staining or 
MPM-2 staining alone, a 1:50 dilution of a FITC-conjugated anti-mouse IgG antibody (Sigma) was used. For p53 and MPM-2 double-staining, a 1:50 dilution of each of a FITC-conjugated anti-mouse IgG2a (Caltag) and a PE-conjugated anti-mouse IgG1 (Caltag) was used. Staining using the secondary antibodies was done for $30 \mathrm{~min}$ at $4^{\circ} \mathrm{C}$. Cells were then washed twice with wash solution and resuspended in FACS buffer $10.1 \%$ sodium azide and $1 \%$ BSA in PBS). Cells were then analyzed by flow cytometry.

\section{Chloramphenicol acetyltransferase assay}

For CAT assays, cells were grown to $5 \times 10^{5} \mathrm{cell} / \mathrm{ml}$ and $1 \times 10^{7}$ cells were electroporated with $10 \mu \mathrm{g}$ of either $\mathrm{pPG}_{13^{-}}$ CAT (containing p53 DNA binding sites) or $\mathrm{pMG}_{15}$-CAT (containing mutated p53 DNA binding sites) (Kern et al. 1992) along with $10 \mu \mathrm{g}$ of pCMVCD20 (Van den Heuvel and Harlow 1993). After $6 \mathrm{hr}, 0.1 \mu \mathrm{g} / \mathrm{ml}$ of nocodazole was added to two-thirds of the cells. At $48 \mathrm{hr}$, cells were stained for CD20 expression using a FITC-conjugated anti-CD20 antibody (Becton Dickinson) and analyzed by flow cytometry for equal transfection efficiencies. Cells were also harvested at $48 \mathrm{hr}$, washed with PBS, and resuspended in $100 \mu \mathrm{l}$ of $0.25 \mathrm{M}$ Tris (pH 7.8). Cells were lysed by three rounds of freezeing and thawing, and cellular debris was cleared by centrifugation at $14,000 \mathrm{~g}$ for $5 \mathrm{~min}$ at $4^{\circ} \mathrm{C}$. Protein concentration was quantitated by Bradford protein assay (Bio$\mathrm{Rad}$ ). Seventy micrograms of acetyl CoA and $1 \mu \mathrm{Ci}$ of ${ }^{14} \mathrm{C}$-chloramphenicol were added to $50 \mu \mathrm{g}$ of protein in $140 \mu \mathrm{l}$ of $1 \mathrm{M}$ Tris $(\mathrm{pH} 7.8)$. The sample was then incubated for $2 \mathrm{hr}$ at $37^{\circ} \mathrm{C}$. After ethyl acetate extraction, the organic layer was lyophilized for 15 min, resuspended in $30 \mu \mathrm{l}$ of ethyl acetate, and spotted on a thin-layer chromatography plate. After separation, the plate was air-dried and exposed to film.

\section{Acknowledgments}

The authors would like to thank Drs. Moshe Oren and Ed Harlow for their generous donation of plasmids; Drs. Steve Kron, Nissam Hay, and Tim McKeithan for thoughtful discussions and review of the manuscript; and Therese Conway for editorial assistance. This work was supported in part by research grant PO1 AI35294 from the National Institutes of Health. L.H.B. was supported by a fellowship from the Leukemia Society of America.

The publication costs of this article were defrayed in part by payment of page charges. This article must therefore be hereby marked "advertisement" in accordance with 18 USC section 1734 solely to indicate this fact.

\section{References}

Agarwal, M.L., A. Agarwal, W.R. Taylor, and G.R. Stark. 1995. p53 controls both the G2/M and the G1 cell cycle checkpoints and mediates reversible growth arrest in human fibroblasts. Proc. Natl. Acad. Sci. 92: 8493-8497.

Boise, L.H., M. Gonzalez-Garcia, C.E. Postema, L. Ding, T. Lindsten, L.A. Turka, X. Mao, G. Nunez, and C.B. Thompson. 1993. $b c l-x$, a $b c l-2-r e l a t e d$ gene that functions as a dominant regulator of apoptotic cell death. Cell 74: 597-608.

Boise, L.H., A.J. Minn, P.J. Noel, C.H. June, M.A. Accavitti, T. Lindsten, and C.B. Thompson. 1995. CD28 costimulation can promote $\mathrm{T}$ cell survival by enhancing the expression of Bcl- $\mathrm{x}_{\mathrm{L}}$. Immunity 3: 87-98.
Canman, C.E., T.M. Gilmer, S.B. Coutts, and M.B. Kastan. 1995. Growth factor modulation of p53-mediated growth arrest versus apoptosis. Genes \& Dev. 9: 600-611.

Clarke, A.R., C.A. Purdie, D.J. Harrison, R.G. Morris, C.C. Bird, M.L. Hooper, and A.H. Wyllie. 1993. Thymocyte apoptosis induced by p53-dependent and independent pathways. $\mathrm{Na}$ ture 362: 849-852.

Cox, L.S. and D.P. Lane. 1995. Tumour suppressors, kinases and clamps: How p53 regulates the cell cycle in response to DNA damage. Bioessays 17: 501-508.

Cross, S.M., C.A. Sanchez, C.A. Morgan, M.K. Schimke, S. Ramel, R.L. Idzerda, W.H. Raskind, and B.J. Reid. 1995. A p53dependent mouse spindle checkpoint. Science 267: 13531356.

Davis, F.M., T.Y. Tsao, S.K. Fowler, and P.N. Rao. 1983. Monoclonal antibodies to mitotic cells. Proc. Natl. Acad. Sci. 80: 2926-2930.

Deng, C., P. Zhang, J.W. Harper, S.J. Elledge, and P. Leder. 1995. Mice lacking p21CIP1/WAF1 undergo normal development, but are defective in Gl checkpoint control. Cell 82: 675684.

Dole, M., G. Nunez, A.K. Merchant, J. Maybaum, C.K. Rode, C.A. Bloch, and V.P. Castle. 1994. Bcl-2 inhibits chemotherapy-induced apoptosis in neuroblastoma. Cancer Res. 54: 3253-3259.

Dole, M.G., R. Jasty, M.J. Cooper, C.B. Thompson, G. Nunez, and V.P. Castle. 1995. Bcl- $\mathrm{x}_{\mathrm{L}}$ is expressed in neuroblastoma cells and modulates chemotherapy-induced apoptosis. Cancer Res. 55: 2576-2582.

El-Deiry, W.S., T. Tokino, V.E. Velculescu, D.B. Levy, R. Parsons, J.M. Trent, D. Lin, W.E. Mercer, K.W. Kinzler, and B. Vogelstein. 1993. WAF1, a potential mediator of p53 tumor suppression. Cell 75: 817-825.

Evan, G.I., L. Brown, M. Whyte, and E. Harrington. 1995. Apoptosis and the cell cycle. Curr. Opin. Cell Biol. 7: 825-834.

Fisher, D.E. 1994. Apoptosis in cancer therapy: Crossing the threshold. Cell 78: 539-542.

Fukasawa, K., T. Choi, R. Kuriyama, S. Rulong, and G.F. Vande Woude. 1996. Abnormal centrosome amplification in the absence of p53. Science 271: 1744-1747.

Haffner, R. and M. Oren. 1995. Biochemical properties and biological effects of p53. Curr. Opin. Genet. Dev. 5: 84-90.

Harper, J.W., G.R. Adami, N. Wei, K. Keyomarsi, and S.J. Elledge. 1993. The p2l Cdk-interacting protein Cipl is a potent inhibitor of Gl cyclin-dependent kinases. Cell 75: 805-816.

Hartwell, L.H. and M.B. Kastan. 1994. Cell cycle control and cancer. Science 266: 1821-1828.

Harvey, M., A.T. Sands, R.S. Weiss, M.E. Hegi, R.W. Wiseman, P. Pantazis, B.C. Giovanella, M.A. Tainsky, A. Bradley, and L.A. Donehower. 1993. In vitro growth characteristics of embryo fibroblasts isolated from p53-deficient mice. Oncogene 8: 2457-2467.

Hockenbery, D.M. 1995. bcl-2, a novel regulator of cell death. BioEssays 17: 631-638.

Hollstein, M., D. Sidransky, B. Vogelstein, and C.C. Harris. 1991. p53 mutations in human cancers. Science 253: 49-53.

Hoyt, M.A., L. Totis, and B.T. Roberts. 1991. S. cerevisiae genes required for cell cycle arrest in response to loss of microtubule function. Cell 66: 507-517.

Kastan, M.B., Q. Zhan, W.S. El-Deiry, F. Carrier, T. Jacks, W.V. Walsh, B.S. Plunkett, B. Vogelstein, and A.J. Fornace Jr. 1992. A mammalian cell cycle checkpoint pathway utilizing p53 and GADD45 is defective in ataxia-telangiectasia. Cell 71: 587-597.

Kern, S.E., J.A. Pietenpol, S. Thiagalingam, A. Seymour, K.W. 
Kinzler, and B. Vogelstein. 1992. Oncogenic forms of p53 inhibit p53-regulated gene expression. Science 256: 827830.

Kuerbitz, S.J., B.S. Plunkett, W.V. Walsh, and M.B. Kastan. 1992. Wild-type p53 is a cell cycle checkpoint determinant following irradiation. Proc. Natl. Acad. Sci. 89: 7491-7495.

Kung, A.L., S.W. Sherwood, and R.T. Schimke. 1990. Cell linespecific differences in the control of cell cycle progression in the absence of mitosis. Proc. Natl. Acad. Sci. 87: 9553-9557.

Li, R. and A.W. Murray. 1991. Feedback control of mitosis in budding yeast. Cell 66: 519-531.

Li, X. and R.B. Nicklas. 1995. Mitotic forces control a cell-cycle checkpoint. Nature 373: 630-632.

Lowe, S.W., H.E. Ruley, T. Jacks, and D.E. Housman. 1993a. p53-dependent apoptosis modulates the cytotoxicity of anticancer agents. Cell 74: 957-967.

Lowe, S.W., E.M. Schmitt, S.W. Smith, B.A. Osborne, and T. Jacks. 1993b. p53 is required for radiation-induced apoptosis in mouse thymocytes. Nature 362: 847-849.

Lowe, S.W., S. Bodis, A. McClatchey, L. Remington, H.E. Ruley, D.E. Fisher, D.E. Housman, and T. Jacks. 1994. p53 status and the efficacy of cancer therapy in vivo. Science 266: 807810.

Metz, T., A.W. Harris, and J.M. Adams. 1995. Absence of p53 allows direct immortalization of hematopoietic cells by the myc and raf oncogenes. Cell 82: 29-36.

Minn, A.J., C.M. Rudin, L.H. Boise, and C.B. Thompson. 1995. Expression of $\mathrm{Bcl}-\mathrm{x}_{\mathrm{L}}$ can confer a multidrug resistance phenotype. Blood 86: 1903-1910.

Minshull, J., H. Sun, N.K. Tonks, and A.W. Murray. 1994. A MAP kinase-dependent spindle assembly checkpoint in Xenopus egg extracts. Cell 79: 475-486.

Miyashita, T. and J.C. Reed. 1993. Bcl-2 oncoprotein blocks chemotherapy-induced apoptosis in a human leukemia cell line. Blood 81: 151-157.

Murray, A.W. 1994. Cell cycle checkpoints. Curr. Opin. Cell Biol. 6: 872-876.

. 1995. The genetics of cell cycle checkpoints. Curr. Opin. Genet. Dev. 5: 5-11.

Rieder, C.L., R.W. Cole, A. Khodjakov, and G. Sluder. 1995. The checkpoint delaying anaphase in response to chromosome monoorientation is mediated by an inhibitory signal produced by unattached kinetochores. J. Cell Biol. 130: 941948.

Sandell, L.L. and V.A. Zakian. 1993. Loss of a yeast telomere: Arrest, recovery, and chromosome loss. Cell 75: 729-739.

Schlaifer, D., M. March, S. Krajewski, G. Laurent, J. Pris, G. Delsol, J.C. Reed, and P. Brousset. 1995. High expression of the bcl-x gene in Reed-Sternberg cells of Hodgkin's disease. Blood 85: 2671-2674.

Shaulian, E., A. Zauberman, D. Ginsberg, and M. Oren. 1992. Identification of a minimal transforming domain of p53: Negative dominance through abrogation of sequence-specific DNA binding. Mol. Cell. Biol. 12: 5581-5592.

Smith, M.L., I.T. Chen, Q. Zhan, I. Bae, C.Y. Chen, T.M. Gilmer, M.B. Kastan, P.M. O'Connor, and A.J. Fornace Jr. 1994. Interaction of the p53-regulated protein Gadd45 with proliferating cell nuclear antigen. Science 266: 1376-1380.

Van den Heuvel, S. and E. Harlow. 1993. Distinct roles for cyclin-dependent kinases in cell cycle control. Science 262: 2050-2054.

Wang, Y. and C. Prives. 1995. Increased and altered DNA binding of human p53 by S and G2/M but not G1 cyclin-dependent kinases. Nature 376: 88-91.

Yin, Y., M.A. Tainsky, F.Z. Bischoff, L.C. Strong, and G.M. Wahl. 1992. Wild-type p53 restores cell cycle control and inhibits gene amplification in cells with mutant p53 alleles. Cell 70: 937-948. 


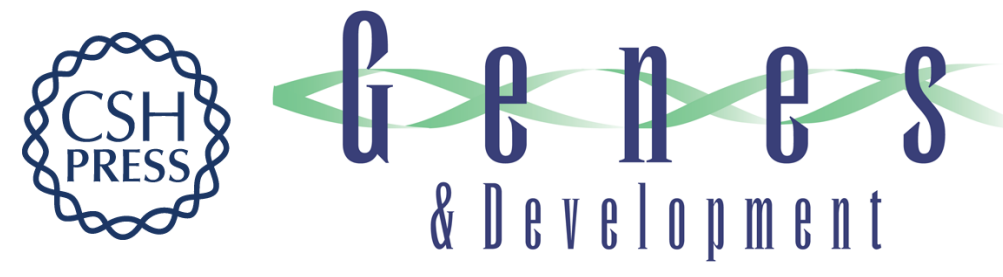

\section{Expression of Bcl-xL and loss of p53 can cooperate to overcome a cell cycle checkpoint induced by mitotic spindle damage.}

A J Minn, L H Boise and C B Thompson

Genes Dev. 1996, 10:

Access the most recent version at doi:10.1101/gad.10.20.2621

References

This article cites 45 articles, 19 of which can be accessed free at: http://genesdev.cshlp.org/content/10/20/2621.full.html\#ref-list-1

License

Email Alerting

Receive free email alerts when new articles cite this article - sign up in the box at the top Service right corner of the article or click here.

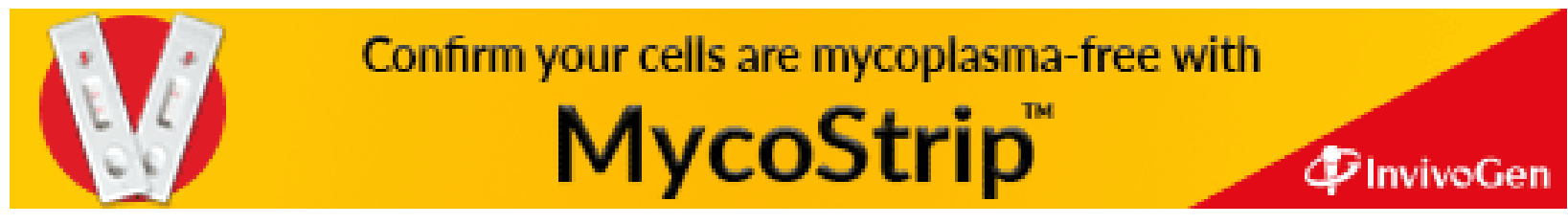

